\title{
Articles
}

\section{Partial Oxidation of Methane over $\mathrm{Ni} / \mathrm{SiO}_{2}$}

\author{
Hyun-Seog Roh, Wen-Sheng Dong, ${ }^{1}$ Ki-Won Jun, ${ }^{*}$ Zhong-Wen Liu, Sang-Eon Park,, and Young-Sam Oh ${ }^{*}$ \\ Catalvsis Center for Molecular Engineering, Korea Research Institute of Chemical Technologv, \\ P.O. Box 107. Yuseong, Daejeon 305-600. Korea \\ LNG Technologr Research Center, Korea Gas Corporation, Incheon t06-130. Korea \\ Received December 8, 2001
}

\begin{abstract}
$\mathrm{Ni}$ catalyst (Ni: $15 \mathrm{wt} \%$ ) supported on precalcined $\mathrm{SiO}_{2}$ has been investigated in reforming reactions of methane to synthesis gas. The catalyst exhibited fairly good activity and stability in partial oxidation of methane (POM). whereas it deactivated in steam reforming of methane (SRM). Pulse reaction results of $\mathrm{CH}_{4}, \mathrm{O}_{2}$, and $\mathrm{CH}_{4} / \mathrm{O}_{2}$ revealed that $\mathrm{Ni} / \mathrm{SiO}_{2}$ has high capability to dissociate methane. The results also revealed that both $\mathrm{CH}_{4}$ and $\mathrm{O}_{2}$ are activated on the surface of metallic $\mathrm{Ni}$. and then surface carbon species react with adsorbed oxygen to produce $\mathrm{CO}$ and $\mathrm{CO}_{2}$ depending on the bond strength of the oxygen species on the catalyst surface.
\end{abstract}

Keywords : Methane, $\mathrm{Ni} / \mathrm{SiO}_{2}$. POM. Pulse reaction, Refonming.

\section{Introduction}

Catalytic partial oxidation of methane (POM) is of great practical importance in producing hydrogen or synthesis gas by using natural gas. ${ }^{1-3}$ Compared with the conventional highly endothermic catalytic steam reforming of methane (SRM). ${ }^{4}$ which is the established process for converting hydrocarbons into hydrogen or synthesis gas in industry, the catalytic POM offers the alternatively greatest potential for fast. efficient and economical conversion of methane to hydrogen or synthesis gas, due to the mild exothermicity. high conversion, high selectivity, suitable $\mathrm{H}_{2} / \mathrm{CO}$ ratio for $\mathrm{C}_{1}$ chemistry, and the very short residence time. Consequently. catalytic POM is estimated to be more econonical than SRM. ${ }^{1}$ Therefore, it is necessary to develop the effective catalyst.

POM was first investigated in the $30{ }^{\circ} \mathrm{s}$ and $40 \mathrm{~s} \mathrm{~s}^{5.6}$ But. coke formation occurred on the metal catalysts at the stoichiometric $\mathrm{CH}_{4} / \mathrm{O}_{2}$ ratio. Such undesirable carbon formation cannot be avoided by increasing the $\mathrm{O}_{4} / \mathrm{CH}_{4}$ ratio or by increasing the operating temperature without also increasing the potential explosion hazards. separation problems, and decreased synthesis gas selectivities. Catalytic POM has thus been virtually ignored for the last 50 years. In 1990 . Green and co-workers ${ }^{7}$ reported that some noble metals could catalyze POM to the thermodynamic equilibrium composition of product gases. This observation reawakened industrial and academic interest in POM. Very recently, we reported that $\mathrm{Ni} / \mathrm{Ce}-\mathrm{ZrO}_{2}$ exhibited high activity and stability in $\mathrm{POM}^{8} \mathrm{SRM}^{5}$ and oxy-stean reforming of methane

\footnotetext{
${ }^{*}$ Corresponding Author. Fax: +82-42-860-7676; e-mail: kwjun $\alpha$ krict.re.kr or separkâkrict.re.kr

'Present address: Institute of Coal Chemistry, Chinese Acadeny of Sciences, Taiyuan 03000 l, P.R. China
}

(OSRM). ${ }^{111}$ Since Choudhary and co-iworkers ${ }^{11}$ reported that $\mathrm{Ni} / \mathrm{MgO}$ showed good activity and selectivity in the reaction, $\mathrm{Ni} / \mathrm{MgO}$ has been considered as one of the best candidate for POM. ${ }^{12}$ They also applied $\mathrm{Ni} / \mathrm{SiO}_{2}$ to $\mathrm{POM}$. but failed to obtain stable activity. ${ }^{13} \mathrm{As}$ a consequence, $\mathrm{Ni} /$ $\mathrm{SiO}_{2}$ has not been considered as a promising catalyst for POM. However, in this work, we found that Ni supported on de-liydrosylated $\mathrm{SiO}_{2}$, which was precalcined at $800^{\circ} \mathrm{C}$ for 6 h. showed fairly good activity corresponding to $\mathrm{Ni} / \mathrm{MgO}$ in POM.

\section{Experimental Section}

Catalyst Preparation and Characteristics. The $\mathrm{SiO}_{2}$ support (99\%. PQ Corp.) employed in this study was precalcined at $800^{\circ} \mathrm{C}$ for $6 \mathrm{~h}$ in order to improve stability at high temperature. $15 \mathrm{wt} \% \mathrm{Ni} / \mathrm{SiO}_{2}$ catalyst was prepared by the molten-salt method as described elsewhere. ${ }^{1+}$ The BET specific surface area and pore volume of the sample were measured by $\mathrm{N}_{2}$ adsorption at $-196^{\circ} \mathrm{C}$ (Micromeritics, ASAP$2400)$. TPR was carried out in a conventional apparatus using $5 \% \mathrm{H}_{2} / \mathrm{N}_{2}$ gas with a heating rate of $10^{\circ} \mathrm{C} / \mathrm{min}$. Pulse chemisorptions were performed in a multifunction apparatus. ${ }^{12}$ The metal dispersion, surface area and average crystallite diameter were calculated based on the methods described in the reference $e^{15}$ by assuming the adsorption stoichiometry of one hydrogen atom per nickel surface atom $\left(\mathrm{H} / \mathrm{Ni}_{\mathrm{s}}=1\right)$.

Reactions. Continuous flow activity tests were carried out under atmospheric pressure in a quartz micro-reactor with an inner diameter of $4 \mathrm{~mm}$. The detailed procedures were described elsewhere. ${ }^{12}$ Pulse experiments using $\mathrm{CH}_{4} . \mathrm{O}_{2}$ and $\mathrm{CH}_{4} / \mathrm{O}_{2}$ mixed gas $\left(\mathrm{CH}_{4} / \mathrm{O}_{2}=2\right)$ were performed under atmospheric pressure in a quartz micro-reactor with an inner diameter of $4 \mathrm{~mm}$ ( $(\mathrm{mL}$ pulse). $50 \mathrm{mg}$ catalysts were loaded into the reactor. The detailed procedures were described 
Table I. Textural properties of $\mathrm{SiO}_{2}$ and $\mathrm{Ni} / \mathrm{SiO}_{2}$

\begin{tabular}{|c|c|c|c|}
\hline Sample & $\begin{array}{c}\text { BI:I surlace area } \\
\left(\mathrm{m}^{2} / \mathrm{g}\right)\end{array}$ & $\begin{array}{c}\text { Pore volume } \\
\text { (mI/g) }\end{array}$ & $\begin{array}{l}\text { Nverage pore } \\
\text { diameter }(\lambda)\end{array}$ \\
\hline $\begin{array}{c}\mathrm{SiO}_{2} \\
\text { (untrealed) }\end{array}$ & 453 & 3.2 & 281 \\
\hline $\begin{array}{c}\mathrm{SiO}_{2} \\
\text { (trealed) }\end{array}$ & 400 & 3.0 & 300 \\
\hline $\mathrm{NiSiO}_{2}$ & 262 & 1.6 & 244 \\
\hline
\end{tabular}

Table 2. $\mathrm{H}_{2}$ pulsc chemisorption results of $\mathrm{Ni} / \mathrm{SiO}_{2}$

\begin{tabular}{cccc}
\hline $\begin{array}{c}\text { II uplake } \\
(\mu \mathrm{mhol} / \mathrm{g} \text { cal })\end{array}$ & $\begin{array}{c}\text { Dispersion } \\
(\%)\end{array}$ & $\begin{array}{c}\text { Vi surface area } \\
\left(\mathrm{mm}^{2} / g\right)\end{array}$ & $\begin{array}{c}\text { Average particle } \\
\text { diameler }(\mathrm{nm})\end{array}$ \\
\hline 3.59 & 0.32 & 0.29 & 303 \\
\hline
\end{tabular}

elsewhere. ${ }^{12}$ The conversion and selectivity were calculated on the basis of $100 \%$ carbon and oxygen balances. In the pulse study, $\mathrm{CO}, \mathrm{CO}_{2}, \mathrm{CO}^{*}$, and $\mathrm{CO}_{2}^{*}$ selectivities were defined as follows.

$\mathrm{CO}$ selectivity $(\%)-$ (moles of $\mathrm{CO}$ formed / moles of $\mathrm{CH}_{4}$ converted) $\times 100 \%$

$\mathrm{CO}_{2}$ selectivity $(\%)-$ (moles of $\mathrm{CO}_{2}$ formed/moles of $\mathrm{CH}_{4}$ converted $) \times 100 \%$

$\mathrm{CO}^{*}$ selectivity $(\%)-(0.5 \times$ moles of $\mathrm{CO}$ formed $/$ moles of $\mathrm{O}_{2}$ converted $) \times 100 \%$

$\mathrm{CO}_{2}{ }^{*}$ selectivity $(\%)-$ (moles of $\mathrm{CO}_{2}$ formed / moles of $\mathrm{O}_{2}$ converted) $\times 100 \%$

\section{Results and Discussion}

Characterization. Table 1 summarizes the typical textural properties of $\mathrm{SiO}_{2}$ and $\mathrm{Ni} / \mathrm{SiO}_{2}$. After $\mathrm{SiO}_{2}$ was precalcined at $900^{\circ} \mathrm{C}$, for $6 \mathrm{~h}$, BET surface area decreased from 453 to $400 \mathrm{~m}^{2} / \mathrm{g}$. This is the evidence of the dehydroxylation of $\mathrm{SiO}_{2}$ during heat treatment. The BET surface area of $\mathrm{Ni} / \mathrm{SiO}_{2}$ is $262 \mathrm{~m}^{2} / \mathrm{g}$. Table 2 presents $\mathrm{I}_{2}$ pulse chemisorption results.

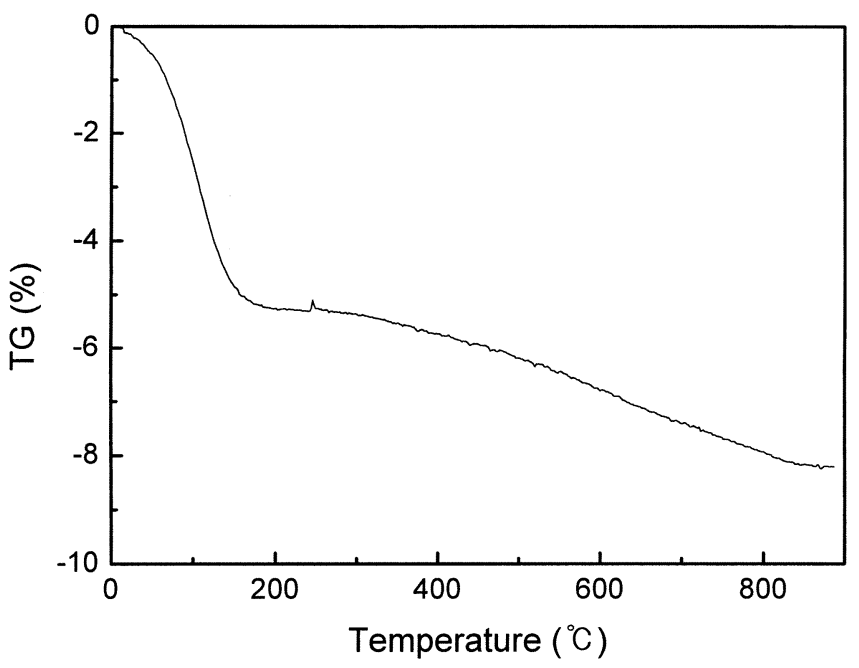

Figure I. $1 \mathrm{GiA}$ curve of $\mathrm{SiO}_{2}$.

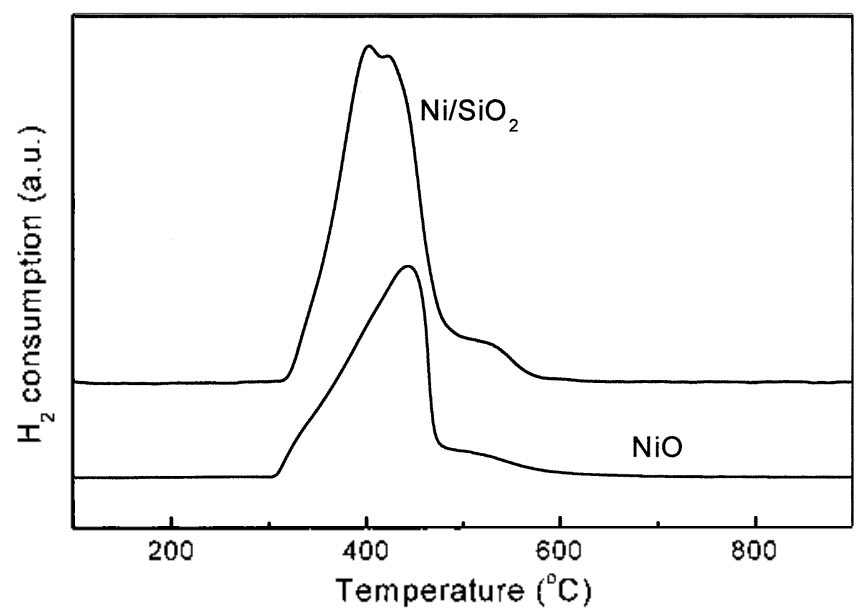

Figure 2. TPR patterns of $\mathrm{NiO}$ and $\mathrm{Ni} / \mathrm{SiO}_{2}$.

$\mathrm{Ni}$ surface area is $0.29 \mathrm{~m}^{2} / \mathrm{g}$ and the average particle diameter of nickel is $303 \mathrm{~mm}$.

The TGA curve of $\mathrm{SiO}_{2}$ is presented in Figure $1 . \mathrm{SiO}_{2}$ shows two distinct stages of weight loss, which are interpreted to be mainly due to removal of water. A first step up to $180^{\circ} \mathrm{C}$, assigned to the desorption of water, and a second step above $180^{\circ} \mathrm{C}$, related to condensation of silanol groups to form siloxane bonds, are clearly visible. This is another evidence of the dehydroxylation of $\mathrm{SiO}_{2}$ during precalcination process.

The TPR patterns of pure $\mathrm{NiO}$ and $\mathrm{Ni} / \mathrm{SiO}_{2}$ are illustrated in Figure 2. Bulk NiO shows a sharp reduction peak at about $450{ }^{\circ} \mathrm{C}$ followed by a small hump. $\mathrm{Ni} / \mathrm{SiO}_{2}$ shows a peak consisting of two components with maxima at 400 and 420 ${ }^{10} \mathrm{C}$. This evidences some inhomogeneity of supported $\mathrm{Ni}$. According to the data from the literature, ${ }^{16}$ the TPR peaks are due to the reduction of NiO. No strong metal to support interaction (SMSI) is typical with silica. ${ }^{16}$

Pulse Reactions. Secjuential pulse experiments $\left(\mathrm{CH}_{4} \rightarrow\right.$ $\mathrm{O}_{2} \rightarrow \mathrm{CH}_{4}$ ) were performed over $\mathrm{Ni}_{3} \mathrm{SiO}_{2}$ at $800{ }^{\circ} \mathrm{C}$ to investigate the $\mathrm{CH}_{4}$ dehydrogenation activity and carbon elimination by $\mathrm{O}_{2}$. In these experiments, five pulses of each gas were injected. The blank run in an empty tube and $\mathrm{CH}_{4}$ pulses over only $\mathrm{SiO}_{2}$ supports did not show detectable $\mathrm{CH}_{\downarrow}$ conversion.

Figure 3 shows $\mathrm{CH}_{4}\left(\mathrm{O}_{2}\right)$ conversion. $\mathrm{CO}\left(\mathrm{CO}^{*}\right)$ and $\mathrm{CO}_{2}$ $\left(\mathrm{CO}_{2}^{*}\right)$ selectivities over $\mathrm{Ni} / \mathrm{SiO}_{2}$ catalyst during three sets of pulses. In the first $\mathrm{CH}_{4}$ pulse, a large amount of $\mathrm{H}_{2}$ and a very small amount of $\mathrm{CO}$ were detected, implying that $\mathrm{CH}_{4}$ is effectively dissociated to form carbon species. Since there was no gas-phase oxygen species present in the system after the prereduction at $700^{\circ} \mathrm{C}$ for $3 \mathrm{~h}$, the oxygen species may originate from the support. However, because reducible oxygen species were very scarce, $\mathrm{CH}_{4}$ conversion rapidly decreased with increasing $\mathrm{CH}_{4}$ pulse resulting from coke formation. There was no $\mathrm{CO}_{2}$ detected during methane pulses. At the same time, the $\mathrm{CO}$ selectivity for the first pulse of methane was only $4.5 \%$. Ni/SiO , exhibited $77 \% \mathrm{CH}_{4}$ conversion. According to our previous result. ${ }^{12} \mathrm{Ni} / \mathrm{MgO}$ showed $39 \% \mathrm{CH}_{4}$ conversion. This is probably due to a 

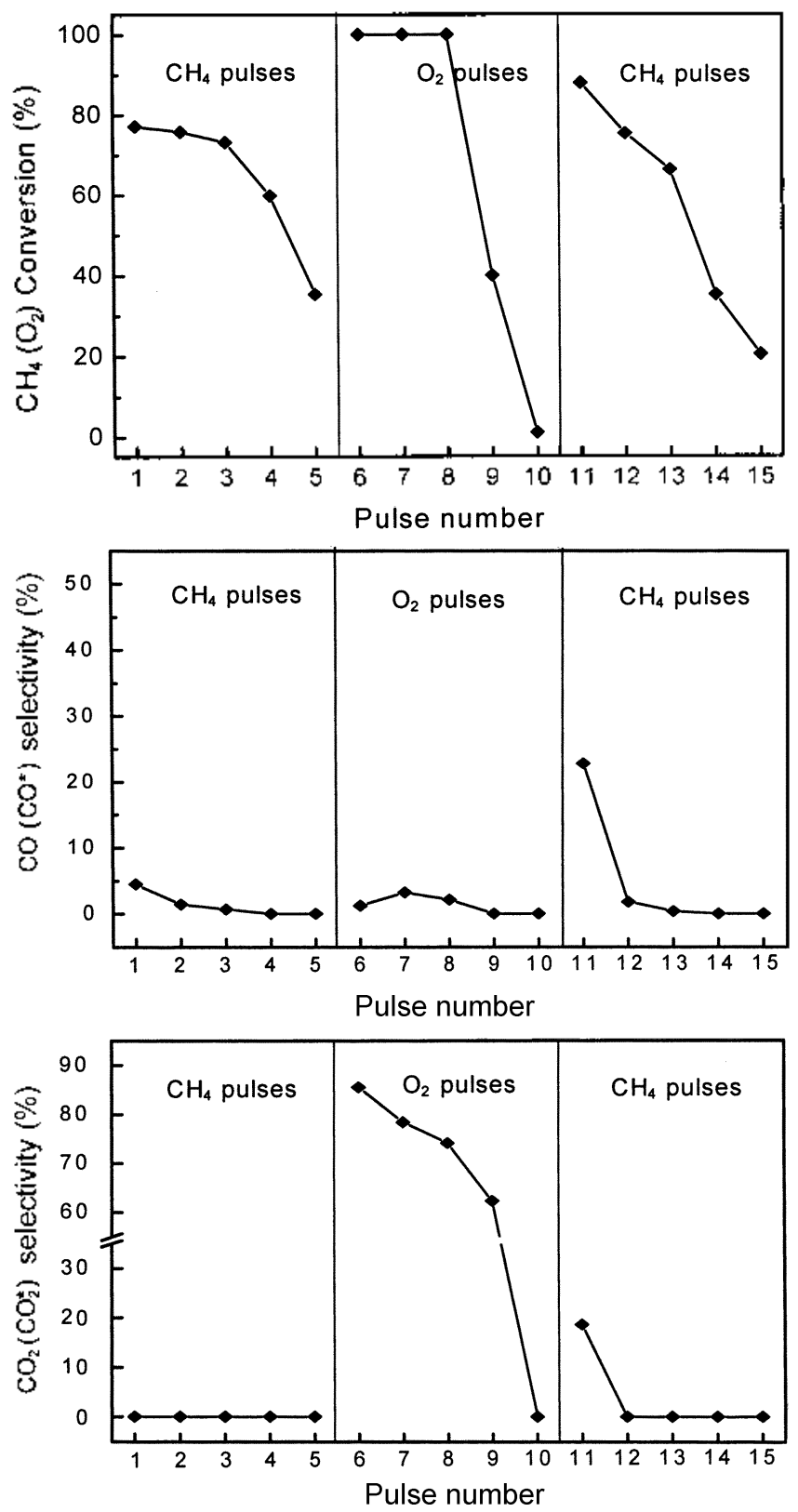

Figure 3. Sequential pulse reaction $\left(\mathrm{CH}_{4} \rightarrow \mathrm{O}_{2} \rightarrow \mathrm{CH}_{4}\right)$ over $\mathrm{Ni} /$ $\mathrm{SiO}=$ at $800^{\circ} \mathrm{C}$.

structural sensitive reaction, which is in agreement with the literature. ${ }^{17}$ Namely, $\mathrm{Ni} / \mathrm{SiO}_{2}$ has no SMSl, whereas $\mathrm{Ni} / \mathrm{MgO}$ has the SMSI. With increasing $\mathrm{CH}_{4}$ pulse, $\mathrm{CH}_{4}$ conversion slowly decreased from $77.5 \%$ in the first pulse to $73.2 \%$ in the third $\mathrm{CH}_{4}$ pulse, and then sharply decreased, suggesting that only when the amount of carbon accumulation on the catalyst is higher than a critical value, the catalyst would be deactivated. In the case of $\mathrm{Ni} / \mathrm{MgO} .{ }^{12} \mathrm{CH}_{4}$ conversion rapidly decreased with increasing $\mathrm{CH}_{4}$ pulse. Compared with $\mathrm{Ni} /$ $\mathrm{MgO}, \mathrm{Ni} / \mathrm{SiO}_{2}$ seems to be less sensitive to carbon accumulation. After five $\mathrm{CH}_{4}$ pulses, the amount of carbon deposited on $\mathrm{Ni} / \mathrm{SiO}_{2}$ was $0.141 \mathrm{mmol}$ (lable 3 ), which is 3 times higher than that on $\mathrm{Ni} / \mathrm{MgO}$, revealing that $\mathrm{Ni} / \mathrm{SiO}_{2}$ has higher capability to dissociate $\mathrm{CH}_{4}$ than $\mathrm{Ni} / \mathrm{MgO}$. This is due to the fact that $\mathrm{Ni} / \mathrm{SiO}_{2}$ has no SMSI, whereas $\mathrm{Ni} / \mathrm{MgO}$ has
Table 3. Pulse reaction results of $\mathrm{Ni} / \mathrm{SiO}_{2}$

\begin{tabular}{|c|c|c|c|}
\hline $\mathrm{CH}_{4}$ pulso & & $\mathrm{O}_{2} \mathrm{pulsc}$ & \\
\hline $\begin{array}{c}\text { C. deposited } \\
(\mathrm{mmol})\end{array}$ & $\begin{array}{c}\text { Crinoved } \\
\text { (mmol) }\end{array}$ & $\begin{array}{c}\text { C residuc } \\
\text { (mmol) }\end{array}$ & $\begin{array}{c}\text { Oadsorbed } \\
\text { (mmol) }\end{array}$ \\
\hline 0.141 & 0.128 & 0.013 & 0.0629 \\
\hline
\end{tabular}

(Condition: $5 \mathrm{CH}_{+}$pulses followed by $50_{2}$ pulses).

the strong interaction between $\mathrm{NiO}$ and $\mathrm{MgO}$. The detailed explanation is as follows. It is believed that hydrocarbon should dissociate to produce highly reactive monatomic carbon $\left(\mathrm{C}_{\alpha}\right)$. If there is an excess of $\mathrm{C}_{\alpha}$, then polymerization to $C_{\beta}$ is possible. $C_{\beta}$ is much less reactive than $C_{\alpha}$. As a result. $\mathrm{C} \beta$ may accumulate on the surface. ${ }^{18}$ During $\mathrm{CH}_{4}$ pulses, because there is no gas phase oxygen species, the polymerization of $\mathrm{C}_{\alpha \alpha}$ to $\mathrm{C}_{\beta}$ is favored especially on $\mathrm{Ni} / \mathrm{SiO}_{2}$ due to much larger $\mathrm{Ni}$ ensemble size than $\mathrm{Ni} / \mathrm{MgO}$.

To investigate the reaction between surface carbides and $\mathrm{O}_{2}$, at step switch from $\mathrm{CH}_{4}$ to $\mathrm{O}_{2}$ flow was carried out after 5 $\mathrm{CH}_{4}$ pulses. A large amount of $\mathrm{CO}$ or $\mathrm{CO}_{2}$ was produced in the first $\mathrm{O}_{2}$ pulse, indicating the carbon species could quickly react with surface $\mathrm{O}$ species to form $\mathrm{CO}$ or $\mathrm{CO}_{2}, \mathrm{Ni}$ $\mathrm{SiO}_{2}$ generated a considerable amount of $\mathrm{CO}_{2}$ until the fourth $\mathrm{O}_{2}$ pulse. These results reveal that the carbon species on $\mathrm{Ni} / \mathrm{SiO}_{2}$ favors $\mathrm{CO}_{2}$ formation. This is probably due to the fact that the bond strength between carbon species and the active metallic $\mathrm{Ni}$ surface on $\mathrm{Ni} / \mathrm{SiO}_{2}$ is very strong. The strong bond mode favors $\mathrm{CO}_{2}$ formation, because carbon species can be easily oxidized further to $\mathrm{CO}_{2}$ by adsorbed $\mathrm{O}$ species. This is due to the reason that the selectivity to $\mathrm{CO}$ is governed mainly by two parallel steps, namely the oxidation of $\mathrm{CO}(\mathrm{s})$ to give $\mathrm{CO}_{2}$ and the desorption of $\mathrm{CO}(\mathrm{s})$ to $\mathrm{CO}(\mathrm{g})$. The activation energy of $\mathrm{CO}(\mathrm{s})$ desorption is nearly double that of $\mathrm{CO}(\mathrm{s})$ oxidation over $\mathrm{Ni}^{1{ }^{19}}$ Therefore, $\mathrm{Ni} / \mathrm{SiO}_{2}$ having the stronger bond strength between carbon species and the $\mathrm{Ni}$ surface favors $\mathrm{CO}_{2}$ formation rather than $\mathrm{CO}$. After tive $\mathrm{O}_{2}$ pulses, the amount of carbon residue was $0.013 \mathrm{mmol}$.

After $\mathrm{O}_{2}$ pulses, some activated oxygen species still remained on the catalysts. In order to investigate the oxygen species involved in $\mathrm{POM}, \mathrm{CH}_{4}$ pulse was re-introduced after $\mathrm{O}_{2}$ pulses. It was found that a considerable amount of $\mathrm{CO}$ and $\mathrm{CO}_{2}$ was generated over $\mathrm{Ni} / \mathrm{SiO}_{2}$ in the first $\mathrm{CH}_{4}$ pulse. $\mathrm{CH}_{4}$ conversions over the partially oxidized catalysts in the third set of pulses were higher than those over the freshly reduced catalysts in the first set of $\mathrm{CH}_{4}$ pulses. This indicates that the oxygen species adsorbed on the catalyst may enhance the conversion of $\mathrm{CH}_{4} . \mathrm{CO}$ selectivity (23\%) was slightly higher than $\mathrm{CO}_{2}$ selectivity $(19 \%)$. It is reported that the relative concentration of adsorbed oxygen to carbon species on the catalyst surface as well as the strength of $\mathrm{O}$ species bound to the catalyst is the crucial factor to determine the selectivity to $\mathrm{CO}$ and $\mathrm{CO}_{2}{ }^{20-22}$ After $\mathrm{O}_{2}$ pulses, two types of adsorbed $\mathrm{O}$ species could be formed over the catalyst. One is the strong bond mode and the other is the relatively weak bond mode. These two $\mathrm{O}$ species show different performance with $\mathrm{CH}_{4}$ pulses. The oxygen with strong bond can oxidize carbon species easily to $\mathrm{CO}_{2}$ due to 

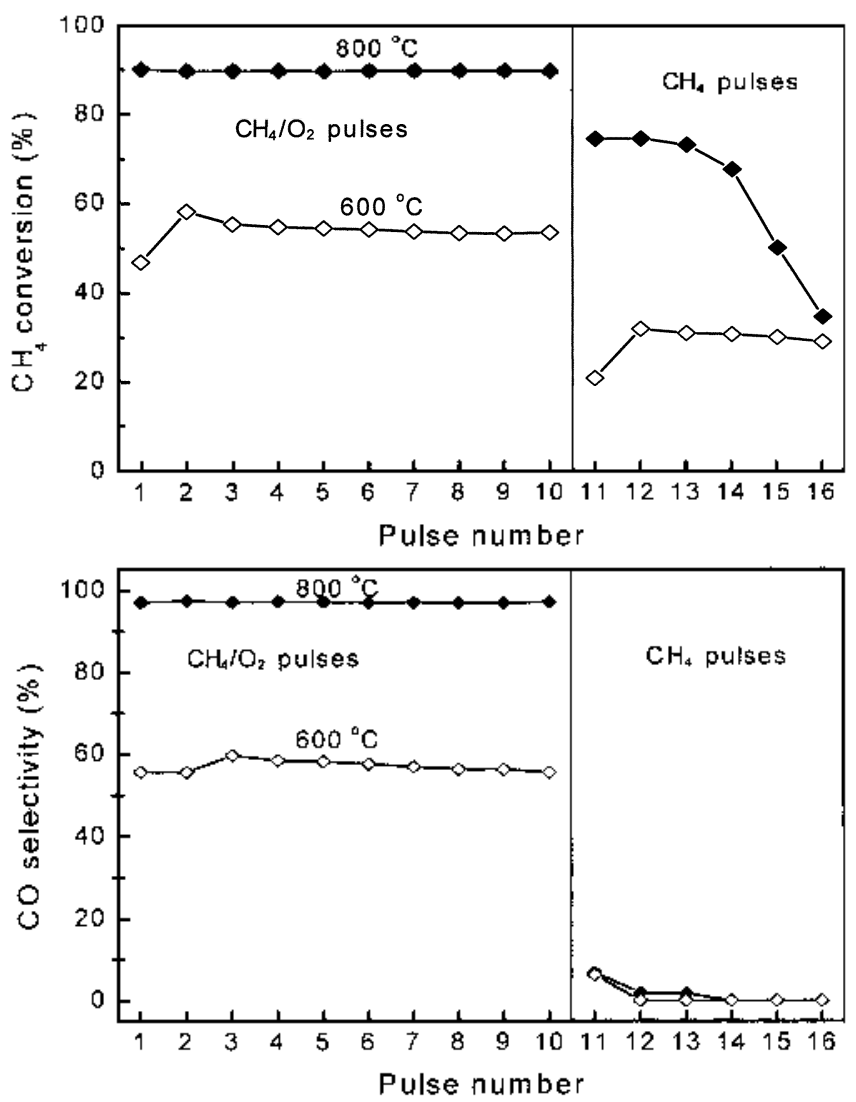

Figure 4. Pulse reaction of $\mathrm{Cl}_{4} / \mathrm{O}_{2}(2 / 1)$ and $\mathrm{Cl}_{4}$ over $\mathrm{Ni} / \mathrm{SiO}_{2}$.

its strong oxidation ability; while the oxygen with relatively weak bond reacts with carbon species to form $\mathrm{CO}$. Since the interaction between $\mathrm{Ni}$ crystallite and $\mathrm{SiO}_{2}$ support is so weak that a large amount of oxygen species having the strong bond strength is formed during $\mathrm{O}_{2}$ pulses. Consequently, it results in better selectivity to $\mathrm{CO}_{2}$ over $\mathrm{Ni} / \mathrm{SiO}$.

The $\mathrm{CH}_{4} / \mathrm{O}_{2}(2 / 1)$ pulse reactions were performed over $\mathrm{Ni} /$ $\mathrm{SiO}_{2}$ catalysts at $600^{\circ} \mathrm{C}$ and $800^{\circ} \mathrm{C}$. respectively. The results are shown in Figure 4. During $\mathrm{CH}_{4} / \mathrm{O}_{2}$ pulses, $\mathrm{O}_{2}$ was completely consumed. $\mathrm{Ni}_{1} \mathrm{SiO}_{2}$ showed about $90 \% \mathrm{CH}_{+}$conversions and $97 \% \mathrm{CO}$ selectivity at $800{ }^{\circ} \mathrm{C}$. which is almost similar to those of $\mathrm{Ni} / \mathrm{MgO} .^{12}$ Comparing with the results in the second set of sequential pulse reaction $\left(\mathrm{O}_{2}\right.$ pulse after $\mathrm{CH}_{4}$ pulses), it is clear that $\mathrm{Ni} / \mathrm{SiO}_{2}$ showed much higher $\mathrm{CO}$ selectivity $(97 \%)$ in pulse reaction of $\mathrm{CH}_{4} / \mathrm{O}_{2}$ at $800{ }^{\circ} \mathrm{C}$. This suggests that only highly reactive carbon species are formed on the catalyst surface by $\mathrm{CH}_{4}$ dissociation to produce $\mathrm{CO}$ during the partial oxidation of mixed $\mathrm{CH}_{4} / \mathrm{O}_{2}$. Comparing the pulse results at $800^{\circ} \mathrm{C}$ with those at $600{ }^{\circ} \mathrm{C}, \mathrm{CO}_{2}$ selectivity decreased with increasing reaction temperature. This is probably due to the following reasons. Since the activation energy of $\mathrm{CO}(\mathrm{s})$ desorption is nearly double that of $\mathrm{CO}(\mathrm{s})$ oxidation over $\mathrm{Ni}$ surface, the increase of reaction temperature would favor $\mathrm{CO}(\mathrm{s})$ desorption, leading to the increase of $\mathrm{CO}$ selectivity. ${ }^{19}$

After 10 pulses of $\mathrm{CH}_{4} / \mathrm{O}_{2}$, pure $\mathrm{CH}_{4}$ was injected. In the first $\mathrm{CH}_{+}$pulse, a considerable amount of $\mathrm{CO}$ was produced without $\mathrm{CO}_{2}$ formation. 'This indicates that some oxygen

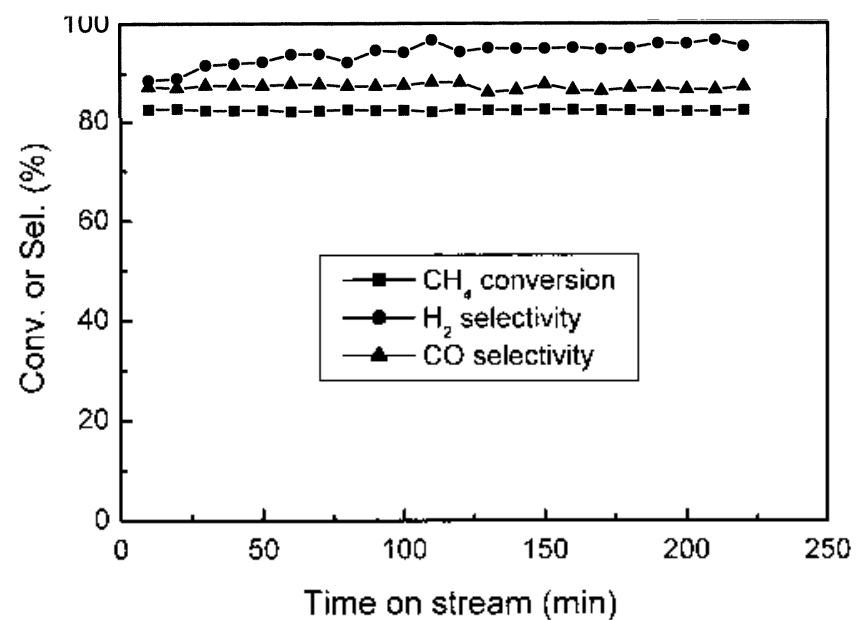

Figure 5. Steady state activities in I'OM over $\left.\mathrm{Ni}_{\mathbf{S}} \mathrm{SiO}\right)_{2}$. (Reaction conditions: $]^{\prime}=750^{\circ} \mathrm{C} . \mathrm{Cll}_{2} \mathrm{O}_{2}=1.875$. (.IISV $=55.200 \mathrm{~mL} / \mathrm{gh}$ ).

species were still present on the catalysts after $\mathrm{CH}_{4} \mathrm{O}_{2}$ pulses, resulting in $\mathrm{CO}$ formation. Thus, it can be reasonably considered that the adsorbed oxygen species play a role as the reaction intermediates in POM. At $600^{\circ} \mathrm{C}, \mathrm{CH}_{4}$ conversion increased from $21 \%$ in the first $\mathrm{CH}_{4}$ pulse to $32 \%$ in the second pulse. The results suggest that $\mathrm{Ni} / \mathrm{SiO}_{2}$ is slightly oxidized at $600^{\circ} \mathrm{C}$. In the first $\mathrm{CH}_{4}$ pulse, $\mathrm{H}_{2}$ produced from $\mathrm{CH}_{4}$ dissociation could reduce the $\mathrm{Ni} / \mathrm{SiO}_{2}$ catalyst, resulting in the increase of $\mathrm{CH}_{4}$ dissociation in the second $\mathrm{CH}_{4}$ pulse.

Steady State Activity in POM. Continuous POM reaction was tested at $750^{\circ} \mathrm{C}$ and space velocity of $55,200 \mathrm{ml} /$ h. $\mathrm{g}_{\mathrm{cal}}$, and the change in $\mathrm{CH}_{4}$ conversion with time on streatn is presented in Figure $5 . \mathrm{Ni} / \mathrm{SiO}_{2}$ exhibited high activity as well as stability during the reaction. It exhibited $83 \% \mathrm{CH}_{4}$ conversion, $95 \% \mathrm{H}_{2}$ selectivity, $88 \% \mathrm{CO}$ selectivity, and a $\mathrm{H}_{2} / \mathrm{CO}$ ratio of 2.1 , suggesting that $\mathrm{Ni} / \mathrm{SiO}_{2}$ is a fairly good POM catalyst compared with the references. ${ }^{8.12}$ According to our previous results, ${ }^{8.12} \mathrm{Ni} / \mathrm{Ce}_{-}-7 . \mathrm{rO}_{2}$ and $\mathrm{Ni} / \mathrm{MgO}$ showed $85 \%$ and $78 \% \mathrm{CH}_{4}$ conversion, respectively. Therefore, it can be suggested that $\mathrm{Ni}_{3} \mathrm{SiO}_{2}$ can be a good candidate in POM. This result is different from Choudhary and co-workers' results. ${ }^{13}$ They reported that $\mathrm{Ni}^{\mathrm{S}} \mathrm{SiO}_{2}$ rapidly deactivated with time on stream. They explained that the deactivation of $\mathrm{Ni} / \mathrm{SiO}_{2}$ was not due to the carbon deposition but due to a strong chemical interaction between $\mathrm{Ni}$ and $\mathrm{SiO}_{2}$. However. in our case, the IPR pattern of $\mathrm{Ni} / \mathrm{SiO}_{2}$ showed no SMSl. This is mainly due to the de-hydroxylation of $\mathrm{SiO}_{2}$ at $800^{\circ} \mathrm{C}$ for $6 \mathrm{~h}$. As a consequence, the defect sites of $\mathrm{SiO}_{2}$ could be eliminated. Hadjijvanov et al. ${ }^{8}$ characterized $\mathrm{Ni}_{\mathrm{SiO}}$ and claimed that no SMSI is typical with $\mathrm{Ni} / \mathrm{SiO}_{2}$ prepared by the impregnation method.

The fact that $\mathrm{Ni} / \mathrm{SiO}_{2}$ shows good activity is in good agreement with the pulse results of methane revealing the high capability of $\mathrm{Ni} / \mathrm{SiO}_{2}$ to dissociate methane. $\mathrm{Ni} / \mathrm{SiO} 2$ maintained stability for several hours without catalyst deactivation. This is ascribed to the high ability to remove the carbon species deposited from $\mathrm{CH}_{4}$ dissociation by adsorbed oxygen species. It is known that the active sites for POM are free $\mathrm{NiO}$ having the weak interaction with the 


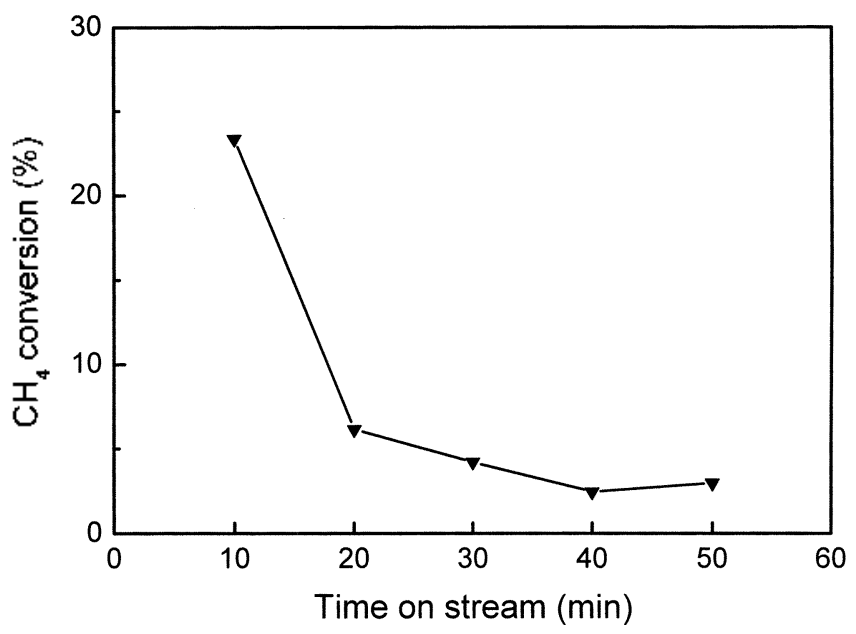

Figure 6. CIL contersion with time on stream in SRM oter $\mathrm{Ni} /$ $\mathrm{SiO}_{2}$. (Reaction conditions: $\mathrm{T}=750^{\circ} \mathrm{C} . \mathrm{H}_{2} \mathrm{O} / \mathrm{CH}_{+}=3.0$. GHSV $=$ $144,000 \mathrm{ml} / \mathrm{gh})$.

support and complex $\mathrm{NiO}_{\mathrm{x}}$ having the strong interaction with the support. ${ }^{810.223}$ Usually, the catalysts having only $\mathrm{NiO}$ are suspected to be sensitive to carbon formation in reforming reactions. Actually, $\mathrm{Ni} / \alpha-\mathrm{Al}_{2} \mathrm{O}_{3}$ deactivated with time on stream. ${ }^{8}$ However, $\mathrm{Ni} / \mathrm{SiO}_{2}$ having no SMSI showed stable activity, resulting from the high capability of $\mathrm{Ni} / \mathrm{SiO}_{2}$ to eliminate the carbon deposited from $\mathrm{CH}_{4}$ decomposition by adsorbed oxygen species. Whereas, $\mathrm{Ni}_{3} \mathrm{SiO}_{2}$ having a chemical interaction did not show stability. ${ }^{1 \overline{3}}$ It may be due to the deactivation of $\mathrm{Ni}$ resulting from the change of physical properties. l ikewise, $\mathrm{Ni} / \gamma \mathrm{Al}_{2} \mathrm{O}_{3}$ would deactivate in $\mathrm{POM}$ as it changes into $\mathrm{NiAl}_{2} \mathrm{O}_{4}{ }^{23}$ Thus, in the case of $\mathrm{Ni} /$ $\mathrm{SiO}_{2}$, a strong chemical interaction between $\mathrm{Ni}$ and support should be prevented to obtain stability in POM.

Steady State Activity in SRM. Steam reforming of methane (SRM) over $\mathrm{Ni} / \mathrm{SiO}_{2}$ was conducted with a $\mathrm{H}_{2} \mathrm{O} / \mathrm{CH}_{4}$ ratio of 3 at $750^{\circ} \mathrm{C}$. As shown in Figure $6 . \mathrm{Ni}^{\circ} \mathrm{SiO}_{2}$ showed very low initial activity $\left(23 \% \mathrm{CH}_{4}\right.$ conversion) and it dramatically deactivated with time on stream. The main reason is that $\mathrm{SiO}_{2}$ is volatile at high steam partial pressure and temperature above $700{ }^{\circ} \mathrm{C}^{2+4} \mathrm{So}$, the structure of $\mathrm{Ni} / \mathrm{SiO}_{2}$ was collapsed by the evaporation of the hydrated silica $\left(\mathrm{Si}(\mathrm{OH})_{4}\right)$. Therefore, it was confirmed that $\mathrm{Ni} / \mathrm{SiO}_{2}$ is not suitable in SRM.

\section{Conclusions}

$\mathrm{Ni}$ supported on de-hydroxylated $\mathrm{SiO}_{2}$ exhibits high activity as well as stability in POM, whereas deactivates in SRM. The high catalytic activity and stability in POM is ascribed to the stabilization of the $\mathrm{SiO}_{2}$ support and the high capability to dissociate $\mathrm{CH}_{4}$ and the ability to eliminate the carbon species by adsorbed $O$ species.

\section{References}

1. Peña. M. A.: Gónez. J. P.: Fierro. J. L. G. Appl. Catat. A 1996. $1+4.7$.

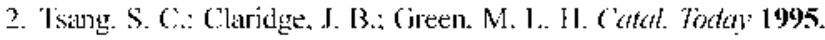
23. 3.

3. Amor. J. N. Appl Catal A 1999. 176. 159.

4. Rostrup-Niclscn. J. R. In Catdific Stem Reforming Catalysis, Science of Techlology: Andersot. I. R.: Boudart. M.. Eds.: Springer: Berlin. 1984: vol. 5.

5. Padovani, C.: l'ruschelli. P. Giron. (Wem. Ind . Applicetta 1933, I5. 429.

6. l'rettre. M.: Eichner. C. H.: Perrin. M. Trams. Faradto Soc 1946. 43.335.

7. Asheroft. A. T.: Cheethant. A. K.: Foord. J. S.: Green. M. L. H.: Grey. C. P.: Murrell. A. 1.: Vernon. P. D. F. Namme 1990. 3ft. 319 .

8. Roh. HI.S.: Dong. W.S.: Jun. K.-W.: Park. S.-I: Chem. Lett. 2001.88.

9. Roh. H.-S.: Jun. K.-W.: Dong. W.-S.: Park. S.-E.: Joc. Y.-I. J. Wol. Catal. 4 2002. 181. 137.

10. Roh. I1,-S.: Jun. K.-W.: Dong W.-S.: Park, S.-E.: Back. Y.S (ctitl. lett. 2001. 7t.31.

II. Choudhary, V. R.; Mamman. A. S.: Sansare. D. Angerw' ('hem. Int Ed. 1992.31.1189.

12. Dong. W.-S.: Roh. H.-S.: Liu. Z.-W.: Jun. K.-W.: Park. S.-E. Bull. Korean Chem. Soc. 2001. 22. 1323.

13. Choudhary. V. R.: Rajput. A. M.: Prabhakar. B.: Mamman. A. S. finel 1998. 77, 1803.

14. Chang. J.-S.: Park, S.-1:.: Chon. II. Appl. C'atat A 1996. 145. 111.

15. Bartholonew. C. H.: Pannell. R. B. J. Catal. 1980. 65.390.

16. Hadjiivanov. K.: Mihaylov. M.: Klissurski. D.: Stetanov. P.: Abadjieva. N.: Vassileva, $\Gamma .:$ Mintchev. 1.. J. (atal. 1999, 185. 314.

17. Beebe T. P. In. Goodman. D. W.: Kay: B. D.: Yales. I. T. It /. Chem. Hows. 1987. 87.2305.

18. Trimm. D. L. Catal. Tokay 1999. 40.3.

19. Au. C. T.: Wang. H. Y.: Wan. H. L. J. Catal. 1996. 158. 343.

20. Shen, S. 1 i. C.: Yu. C. Stud Suff Sci Catol 1998, 119.765.

21. Jin. R.: Chen. Y.: I.i. W.: Cui. W.: Ji. Y.: Yu. C.: Jiane. Y. dppt. ('atat. A 2000). 201. 71.

22. Hu. Y. H.: Ruckenstein. E. J. Catal. 1996. 158.260.

23. Roh. H.-S.: Jun. K.-W.: Dong. W.-S.: Park. S.-E.: Joc. Y.-I. Chem. Lett. 2001. 666.

24. Kochlowt. K. In Handbook of /eterogeneous (atalysis: Ertl. (i.. Knözinger. Il. Weitkamp. I.. Ids.: VCII: Veinhein. 1997: vol. 4. г 1820 . 